\title{
Bivalve clearance rates: inaccurate measurements or inaccurate reviews and misrepresentation?
}

\author{
John Widdows* \\ Plymouth Marine Laboratory, Prospect Place, West Hoe, Plymouth PL1 3DH, United Kingdom
}

The issue of clearance rate measurements, and the range of techniques and their accuracy, has been raised by Riisgård (2001) in his review: 'On measurement of filtration rates in bivalves - the stony road to reliable data: review and interpretation'. His main conclusion is that a large proportion of published studies have used methods that are flawed and that only those studies that show maximum filtration rates measured under optimal laboratory conditions (Table 1; Riisgård 2001) are valid. He either ignores or dismisses the majority of the world literature on bivalve feeding rates.

Riisgård's conclusions appear to be largely based on incorrect interpretation and inaccurate statements concerning the literature. The criticisms of the flowthrough chamber method (i.e. avoidance of water recirculation, geometry of chamber, flow rates and the appropriate equations) formulated by Riisgård (2001) were all recognised more than 20 yr ago and were outlined in the procedures described by Widdows (1985a). While it should not come as a surprise to readers that today's techniques and understanding are better than 30 to 40 yr ago, the arguments put forward by Riisgård (2001) do not apply to the majority of studies performed in the last $20 \mathrm{yr}$. His conclusions are largely based on inaccuracies concerning the literature. For example, he states that 'following the recommendation by Widdows (1985a), Smaal \& Twisk (1997) used a con-

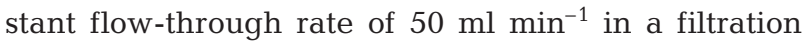
study with $M$. edulis'. However, Widdows (1985a) recommended flow rate $>150 \mathrm{ml} \mathrm{min}^{-1}$ for the 'flowthrough chamber method', whereas $50 \mathrm{ml} \mathrm{min}^{-1}$ together with adequate mixing was the flow rate suggested for the method of Hildreth \& Crisp (1976), referred to by Riisgård as the 'steady-state method'. Furthermore, Widdows (1985a) compared the 'flowthrough chamber' and 'steady-state method', together

*E-mail: j.widdows@pml.ac.uk with the 'closed chamber or indirect method', and found no significant differences in the measured clearance rates.

The most important research question and environmental issue is: 'Why are suspension feeders not performing at their maximum clearance rate?' This is due to a range on environmental factors, including natural variables such as food quality and quantity (Hawkins et al. 2001), temperature (Bayne et al. 1977), salinity (Widdows 1985b), as well as pollution (Widdows \& Donkin 1992, Widdows et al. 1995a). However, these and the majority of other bivalve feeding studies conducted world-wide have been dismissed and ignored by Riisgård (2001), simply because the animals are not feeding at their maximal rate. Research has clearly demonstrated that there are several reasons why bivalves are not feeding at their maximal rate: (1) there are regulatory responses to changes in the quality/ quantity of suspended particles (Hawkins et al. 2001); (2) salinity and temperature conditions may be beyond the range of complete acclimation for the population/ species (Bayne et al. 1977, Widdows 1985b); and (3) pollutants in the water and accumulated in the body tissues are inducing an inhibitory effect on feeding activity (Widdows \& Donkin 1992, Widdows et al. 1995a).

I am only focussing on the third aspect here as this work has been rejected by Riisgård (2001). The overwhelming evidence from laboratory, mesocosm and field studies is that environmentally realistic concentrations of toxicants induce an inhibitory effect on suspension feeding rate (reviewed by Widdows \& Donkin 1992, Widdows et al. 1995a). Despite measuring bivalve feeding rate under near optimal conditions (of temperature, salinity, food quality/quantity and high water quality, as stated in the methods of Widdows 1985a, 1993), mussels collected from the majority of coastal and estuarine sites in the UK and elsewhere (Widdows \& Johnson 1988, Widdows et al. 1990, 1995a) do not filter feed at their maximum potential due to the 
presence of pollutants in their body tissues. The maximal feeding rates recorded by Møhlenberg \& Riisgård (1979) and included in Table 1 of Riisgård (2001) probably reflect the origin of the animals, which were collected from the northern part of the Øresund in Denmark. However, the 'optimal' environmental conditions at this site are probably atypical and relatively few animals living in the coastal waters of densely populated and industrialised Europe are feeding and growing under 'optimal' conditions. The majority of mussel populations studied along the North Sea coastline (Widdows et al. 1995a) and more recently the Irish Sea coastline (Widdows et al. in press) have depressed clearance rates (i.e. significantly below maximum rates), primarily due to pollution and reduced water quality (i.e. effects of food, temperature and salinity are removed). High feeding rates (ca $7 \mathrm{lg}^{-1} \mathrm{~h}^{-1}$ ), comparable to the bivalves in the Øresund, have been consistently recorded in mussels originating from pristine North Atlantic coastal sites, such as the Shetlands (Widdows et al. 1995a,b) and the west coast of Scotland (Widdows et al. in press), and far removed from urban/industrial developments. Mussels from a total of 64 coastal sites were measured at the Plymouth Marine Laboratory under standardised 'near optimal' laboratory conditions using clean offshore seawater designed to maximise the clearance rates. Maximal rates were only recorded in ca $20 \%$ of the mussel populations.

Once again Riisgård (2001) makes the assumption that the 'filtration rates are wrongly determined' in the North Sea mussels study and chooses to selectively mis-quote and mis-interpret the detailed findings presented in Widdows et al. (1995a). Riisgård chooses to use such terms as 'allegedly due to different degrees of pollution', but only highlighting the presence of the 'unexplained component' and not the 'explained component'. The fact that given the nature and scale of the survey there is consistency in the data and the reduction in clearance rate and SFG (scope for growth) can be explained by quantitative toxicological interpretation of tissue residue data (i.e. measured contaminants) in more than half of the sites is selectively ignored by Riisgård (2001). The fact that we identify an 'unexplained component' to the reduced scope for growth at many sites does not reflect the inaccurate measurement of clearance rate, but rather the presence and influence of unidentified contaminants. This finding is not surprising, and is now widely acknowledged, because routine chemical analyses of contaminants in the aquatic environment only quantify a small percentage of the total pollutant load. Furthermore, the spatial changes in water quality and the presence of unidentified toxicants, recorded in the North Sea mussels study, have subsequently been confirmed by other pol- lution studies using different techniques, specifically modified to improve sensitivity and detection limits (Kirby et al. 1998).

Riisgård (2001) also comments that 'it is difficult to see the advantages of the SFG technique in field monitoring programmes' in comparison to 'the precise measurement of actual growth of mussels in bags', again adding 'particularly not if the filtration rates are wrongly determined'. However, the advantages of SFG over actual growth measurement have been stated by Widdows \& Donkin (1992), Widdows (1993) and Widdows et al. (1995a). The 2 major advantages are firstly, that when measured under standardised conditions (with food availability, temperature, salinity and dissolved oxygen held constant) the SFG reflects the underlying toxic effects of pollutants accumulated in the body tissues. Furthermore, the effects on SFG can be interpreted in relation to pollution through a quantitative toxicological interpretation of tissue residue chemistry. Secondly, given the considerable variability in growth due to spatial and temporal variability in food quality and quantity, it is difficult to interpret any measured changes in actual growth because it is not possible to separate and distinguish between 'nutritional effects' and 'toxicant effects'. The ability to carry out precise measurements of actual growth will not advance our understanding or provide an interpretation of the causes of reduced growth.

Finally, it is not clear why Riisgård chose to use the metaphor of a 'stony road' in the title of his review. However, anyone travelling along a 'stony road' (perceived or otherwise) should look and check carefully because they may trip up, or be going up a 'blind alley'.

\section{LITERATURE CITED}

Bayne BL, Widdows J, Worrall C (1977) Some temperature relationships in the physiology of two ecologically distinct bivalve populations. In: Vernberg FJ, Calabrese A, Thurberg FP, Vernberg WB (eds) Physiological responses of marine biota to pollutants. Academic Press, New York, p 379-400

Hawkins AJS, Fang JG, Pascoe PL, Zhang JH, Zhang XL, Zhu MY (2001) Modelling short-term responsive adjustments in particle clearance rate among bivalve suspension-feeders: separate unimodal effects of seston volume and composition in the scallop Chlamys farreri. J Exp Mar Biol Ecol 262:61-73

Hildreth DI, Crisp DJ (1976) A corrected formula for calculation of filtration rate of bivalve molluscs in an experimental flowing system. J Mar Biol Assoc UK 56:111-120

Kirby MF, Blackburn MA, Thain JE, Waldock MJ (1998) Assessment of water quality in estuarine and coastal waters of England and Wales using a contaminant concentration technique. Mar Pollut Bull 36:631-642

Møhlenberg F, Riisgård RU (1979) Filtration rate, using a new indirect technique, in thirteen species of suspension feeding bivalves. Mar Biol 54:143-148 
Riisgård HU (2001) On measurement of filtration rates in bivalves - the stony road to reliable data: review and interpretation. Mar Ecol Prog Ser 211:275-291

Smaal AC, Twisk F (1997) Filtration and absorption of Phaeocystis cf. globosa by the mussel Mytilus edulis L. J Exp Mar Biol Ecol 209:33-46

Widdows J (1985a) Physiological procedures. In: Bayne BL, Brown DA, Burns K, Dixon DR and 6 others (eds) The effects of stress and pollution on marine animals. Praeger, New York, p 161-178

Widdows J (1985b) The effects of fluctuating and abrupt changes in salinity on the performance of Mytilus edulis. In: Gray JS, Christiansen ME (eds) Marine biology of polar regions and effects of stress on marine organisms. J Wiley, Chichester, p 555-566

Widdows J (1993) Marine and estuarine invertebrate toxicity tests. In: Calow P (ed) Handbook of Ecotoxicology, Vol. 1, Chap. 9. Blackwell Scientific, p 145-166

Widdows J, Donkin P (1992) Mussels and environmental contaminants: bioaccumulation and physiological aspects. In: Gosling E (ed) The mussel Mytilus: ecology, physio- logy, genetics and culture. Elsevier, Amsterdam, p 383-424

Widdows J, Johnson D (1988) Physiological energetics of Mytilus edulis: scope for growth. Mar Ecol Prog Ser 46: 113-121

Widdows J, Burns KA, Menon NR, Page DS, Soria S (1990) Measurement of physiological energetics (scope for growth) and chemical contaminants in mussels (Arca zebra) transplanted along a contaminant gradient in Bermuda. J Exp Mar Biol Ecol 138:99-117

Widdows J, Donkin P, Brinsley MD, Evans SV and 4 others (1995a) Scope for growth and contaminant levels in North Sea mussels Mytilus edulis. Mar Ecol Prog Ser 127: 131-148

Widdows J, Donkin P, Evans SV, Page DS, Salkeld PN (1995b) Sublethal biological effects and chemical monitoring of Sullom Voe (Shetland) using mussels (Mytilus edulis). Proc R Soc Edin 103B: 99-112.

Widdows J, Donkin P, Staff FJ, Matthiessen P and 5 others (in press) Measurement of stress effects (scope for growth) and contaminant levels in mussels (Mytilus edulis) collected from the Irish Sea. Mar Environ Res 